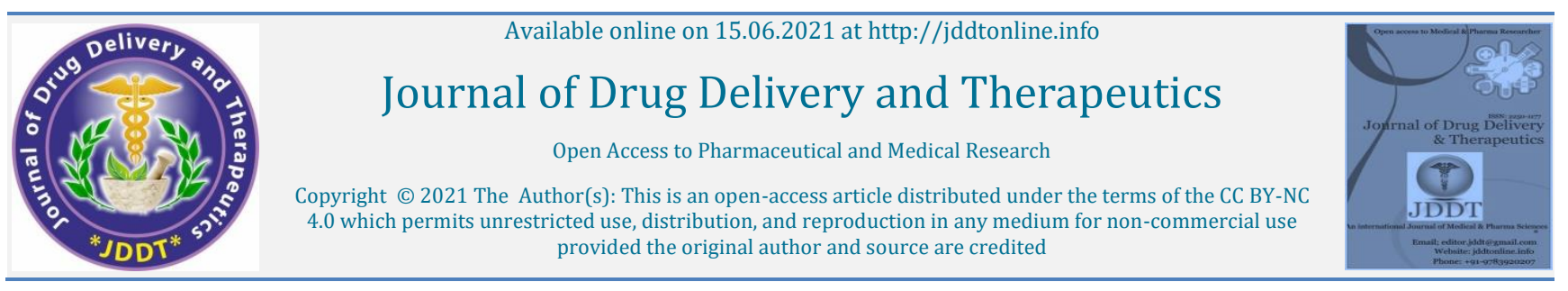

\title{
A review on Effectivity of Plant based vaccines in the treatment of viral diseases
}

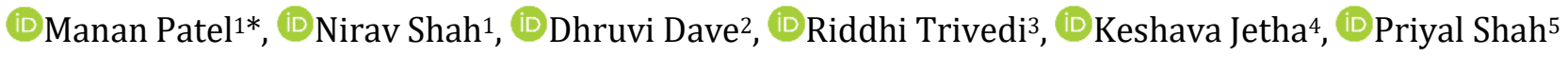

\author{
${ }^{1}$ Assistant Professor, Department of Pharmaceutics, Sal Institute of pharmacy, Gujarat, India \\ ${ }^{2}$ Associate Professor, Department of Pharmaceutics, Sal Institute of pharmacy, Gujarat, India \\ ${ }^{3}$ Professor, Head of the Pharmaceutics Department, Sal Institute of Pharmacy, Gujarat, India \\ ${ }^{4}$ Research Scholar, Department of Pharmaceutics, L. M. College of Pharmacy, Gujarat, India \\ ${ }^{5}$ Research Scholar, Department of Pharmaceutical Quality Assurance and PharmaceuticalChemistry, L. M. College of Pharmacy, Gujarat, India
}

\section{Article Info:

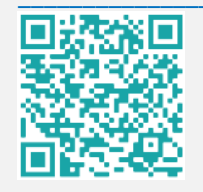 \\ Article History: \\ Received 09 April 2021 \\ Review Completed 23 May 2021 \\ Accepted 29 May 2021 \\ Available online 15 June 2021}

\section{Cite this article as:}

Patel M, Shah N, Dave D, Trivedi R, Jetha K, Shah P, A review on Effectivity of Plant based vaccines in the treatment of viral diseases, Journal of Drug Delivery and Therapeutics. 2021; 11(3-S):90-97

DOI: http://dx.doi.org/10.22270/jddt.v11i3-S.4872

\section{Abstract}

Plant engineering technology has been working effectively since last 30 years Commercialization of different product using plant engineering is encouraging us to develop effective treatment and this progress takes too much effort and time, but still many candidate vaccines for use in humans are in clinical trials. Virus-like particles (VLPs) are basically self-constructed structures departed from viral antigens which copy the organization of similar viruses but without viral genome. This technology offers several pros in terms of safety, immunogenicity and stability in production over vaccines derived from pathogen formulation. Now, many pharmaceutical companies are working in this technology to develop effective treatment against various diseases. This review discusses how plant engineering technology works for diseases and regulations relevant to the development of plant-based vaccines in the treatment of viruses like Hepatitis B, Ebola, Papilloma, Norwalk, Influenza, HIV and Covid-19.

Keywords: Plant engineering technology, Virus-like Particles, Pathogens, Antibodies.

*Address for Correspondence:

Manan Patel, Assistant Professor, SAL Institute of Pharmacy, Opp. Science city, Sola-Bhadaj Road, Ahmedabad, Gujarat, India, 380060.

ORCID: https://orcid.org/0000-0003-2077-9659

\section{INTRODUCTION}

Virus-like particles (VLPs) are basically self-constructed structures departed from viral antigens which copy the organization of similar viruses but without viral genome. They offer several merits in terms of safety, immunogenicity and stability in production over vaccines derived from pathogen formulation or subunit antigens and hence, have earned huge momentum as a premier vaccine platform. ${ }^{1}$ While attenuated or killed pathogens promote powerful immune responses and are still the key source of protection from several infectious diseases, significant reversion of attenuated pathogens or restricted inactivation of killed pathogens in the vaccine has remained a considerable safety concern. Furthermore, for a great number of pathogens either a safe attenuated strain is not yet obtained or no tissue culture system is available to permit its sufficient propagation and production. The development of subunit vaccines via genetic engineering has efficiency to overtake whole pathogen vaccines and associated risks. Notably, vaccines made up of individual proteins hardly possess antigenic determinant sites in their native conformation and hence, are significantly less effective than whole pathogen preparations. As a result subunit vaccines often need larger and more frequent administrations of antigen along with adjuvants to stimulate the desirable immune responses. VLPs possess the best traits of whole-virus as well as subunit antigens for the development of vaccine. VLPs are deficit of viral nucleic acid and are noninfectious. Hence, are safer alternatives of vaccine than attenuated or inactivated viruses. Additionally, the potency of VLPs can be considerably increased over the native virus when immunosuppressive viral proteins are exempted from VLP composition. Also, any undesirable epitope modification by the inactivation of live virus can be eluded for VLP manufacturing that further confirms the VLP's immunogenicity. Given that VLPs act as an infectious virus structurally, they can generate humoral immune and effective cellular responses even without adjuvants, which are more effective than other recombinant antigens. In addition to this, VLPs are highly stable than subunit vaccines and that can be formulated with help of recombinant technology in expression systems with no requirement of the capability to aid viral replication ${ }^{1-3}$.

\section{Plants as Production System for VLPs}

Plants offer a great substitute for VLP vaccine manufacture due to their ability of producing huge quantities of recombinant protein at cheaper costs. Their eukaryotic processing mechanism for the post- translational 
modification and appropriate set-up of proteins, and the low-risk of introducing fortuitous human pathogens 4,5. Plants do not need costly fermentation facilities for biomass production or the generation of duplicate facilities to scale-up production. Therefore, plant biomass generation and upstream processing capacity can be controlled and scaled-up in a desirable, capital-efficient way whichcannot be easily compared by recent fermentation-based technologies 6,7. Certain VLPs were primarilyexpressed in plants and they gave appreciable results, however, these earlier trials had to suffer from several demerits including less VLP expression, plant-specific glycosylation of glycoproteins, and the lack of ability to produce VLPs with multiple proteins ${ }^{8}$. Despite the fact, these challenges have all been overcome by latest development of new plant expression systems and improvement in plant glycoengineering. For instance, the initial production of VLPs in plants was quite slow and it yielded very low product. This issue demonstrates the intrinsic boundaries of early expression systems based upon stable transgenic plants, involving the lack of powerful regulatory elements to operate adequate amounts of target protein accumulation and also undesirable position effects emerged by the uncertainty of transgene integration in plant genome 9,10 . Because of low production yield, VLP production became impractical and it considerably reduced the costsaving merit of plants ${ }^{11}$. The challenges involved in VLP production speed and yield have been overcome by the development of plant virus-based transientplant expression systems 12,13 . The cloning and high-level transient expression of plant-derived VLPs is quite easy and can be acquired rapidly in 1-2 weeks of vector infiltration with a tobacco mosaic virus (TMV) RNA replicon (the MagnICON) system or a gemini viral DNA replicon system based upon beanyellow dwarf virus (BeYDV) 14-16. These new technologies in the rate and quantity of yield of VLP production also offer the plant-expression system an important feature of high versatility in producing VLP vaccines in opposition to the viruses which mutate their surface antigens rapidly, hence fulfilling a specific advantage over other production systems in producing vaccines to cope with unavoidable pandemics (e.g., influenza A) in a timely manner. Likewise, the problem of plant-specific glycans has been satisfyingly overcome by the evolution of transgenic plant lines with "humanized" glycosylation pathways (see glycosylation section below). Additionally, effective production and fabrication of VLPs with up to three different kinds of proteins have also been obtained in plants 17,18 .

\section{Plant-Derived VLPs May Provide a Novel Vehicle for Delivery of Vaccines in the treatment of Diseases}

\section{Plant-derived hepatitis B surface antigen employed in oral immunization studies}

Eliciting an immune response in humans through oral delivery of slightly processed plant material expressing vaccine antigens is achievable. Both vaccines tested till date was aimed opposing to enteric pathogens, namely, Norwalk virus 19 and entero toxigenic Escherichia coli 20. Recently, this idea has been expanded to non-enteric pathogens with the satisfactory demonstration. Hepatitis B surface antigen (HBsAg), conveyed in transgenic potato tubers was immunogenic in animals when given orally 21,22 . Approximately 2 billion people have been contaminated by the hepatitis B virus (HBV) and $15-17 \%$ of the infected characteristic as active carriers, with the maximum endemicity happening among developing countries ${ }^{23}$. A yeast-derived HBV subunit vaccine antigen has been successfully conveyed from plants. The HBsAg was found to gather intracellularly as tubules, with a complex size distribution, drastically varying from the VLP preparations of the current commercial vaccines. The present injectable vaccines possess the standard to compare. It has now been demonstrated that the plant-derived HBsAg was made up of long filaments packed within the Endoplasmic reticulum (ER) 24-29. Also, the antigen was linked with the ER membrane itself, from which the filaments are derived 30 . This structure is fundamentally non-identical to the recent injectable vaccines, which comprise of VLPs with the uniform size of 20-22 $\mathrm{nm} 31,32$. However, recently undertaken animal trials have revealed that the tuberderived antigen was capable of eliciting a primary immune response signaling that a VLP structure was not critical for effectiveness of HBsAg as a vaccine. The extent of disulfide bonding would be more important, which is crucial for presentation of immunogenic epitope. Results have demonstrated that small HBV surface protein (SHBs) dimers predominate the plant-derived antigen acquired from all three recombinant systems. It has also been reported that the dimer form of SHBs possesses all the essential epitopes for immunogenicity 33. The degree of intermolecular disulfide bonding spotted was identical to a yeast-derived vaccine which is currently being marketed 34 . Depending upon the expression system, from $21 \%$ to $37 \%$ of total SHBs were reactive to the Auszyme diagnostic kit, an immunoassay which is performed to determine the potency of any commercial vaccine 35 .

\section{In the treatment of Ebola virus}

No counter measures available as of now for the management of the severe Filovirus (e.g., Ebola virus; EBOV) infection 36,37 . Specifically designed monoclonal antibodies (mAbs) which could be used in humans as immune protectants for EBOV to overcome this limitation, starting with a murine mAb (13F6) which identifies the heavily glycosylated mucin-like structure of the virion-attached glycoprotein (GP). Point mutations were administered into the variable region of the murine mAb to discard predicted human T-cell epitopes, and the variable regions linked to human constant regions to produce a mAb (h-13F6) suitable for human administration. The potency of three variants of h-13F6 having diverse glycosylation patterns in a lethal mouse EBOV challenge model was evaluated 38, 39. The flow of glycosylation of the various mAbs was established to compare to the degree of protection, with aglycosylated $\mathrm{h}$ $13 \mathrm{~F} 6$ possessing the least potency (ED50 $=33 \mu \mathrm{g}$ ). A variant with typical heterogenous mammalian glycoforms (ED50 = $11 \mu \mathrm{g}$ ) had similar efficacy to the native murine mAb. Although, h-13F6 possessing complex N-glycosylation lacking fundamental fucose provided enhanced potency $($ ED50 $=3 \mu \mathrm{g})$. Binding studies with use of $\mathrm{Fc} \gamma$ receptors demonstrated increased attachment of non-gucosylated h13F6 to human and mouse FcyRIII. Combinedly, the results confirm the existence of $\mathrm{Fc} \mathrm{N}$-glycans, which intensify the protective efficacy of $\mathrm{h}-13 \mathrm{~F} 6$, and the mAbs produced with uniform glycosylation and greater potency of glycol form proposes a promising biodefense therapeutic 40 .

\section{In the treatment of Papillomavirus}

Vaccines used for Human papillomavirus (HPV), Cervarix ${ }^{\circledR}$ and Gardasil ${ }^{\circ}$, consist of virus like particles (VLP) according to the primary capsid protein, L1, HPV16 and HPV18. Both vaccines are greatly efficient at preventing persistent infection and more progressive conditions related to HPV16 and HPV18 41,42 . Antibodies which are capable of containing pseudoviruses constituting HPV16 and HPV18 both can be observed in the serum and cervico-vaginal secretions of vaccines 43- 45. Passive transfer studies establishing that 
immune sera, purified IgG or monoclonal antibodies (MAbs) can defend animals from papillomavirus challenge 46-48, have led to the belief that neutralizing antibodies can help to achieve vaccine-induced type-specific protection 49,50 . The vaccines grant an extent of cross- protection against some genetically-related types from the alpha-9 (HPV16-like: HPV33, HPV31, HPV52, HPV35, HPV58) and alpha-7 (HPV18-like: HPV45, HPV39, HPV68, HPV59) groups of species. Cross-protection is concurrent with the observation of low titer serum responses against non-vaccine types by vaccines. Those kind of antibodies may be the mediator of detection and their cross protection may be helpful as a correlate or surrogate. Antibodies produced after Cervarix ${ }^{\circledR}$ were analyzed by pseudo virus neutralization after the vaccination on 13-14 year old girls, ${ }^{51}$ VLP ELISA and by enrichment of target antigen specificity using VLP immobilized beads. Twodimensional serology data recommended that, antibody specificity profile generated by VLP ELISA was qualitatively as well as quantitatively non- identical from the neutralizing antibodies specificity profile 52,53. Targetspecific antibody enrichment showed that crossneutralization of non-vaccine types was because of minority of antibodies higher than by weak interactions of a predominantly type-restricted HPV16 antibody specificity. In addition to this, cross-neutralization of non-vaccine types appeared to be mediated by numerous antibody specificities, many non-vaccine types, recognizing single and whose specificities were not identifiable from examination of the serum neutralizing antibody profile. These data help to understand that the antibody specifications elicited after HPV vaccination and have remarkable implications for vaccine induced cross-protection.

\section{In the treatment of Rabies virus:}

Using engineered amino virus-based vectors is a novel approach to the manufacture and delivery of vaccine antigens. A chimeric peptide containing antigenic determinants from rabies virus glycoprotein ( $G$ protein) (amino acids 253-275) and nucleoprotein ( $\mathrm{N}$ protein) (amino acids 404-418) was PCR- amplified and cloned as a translational fusion product with the alfalfa mosaic virus (AlMV) coat protein (CP) 54-63. This recombinant CP was indicated in two plant virus-based expression systems. The first one utilized transgenic Nicotiana tabacum cv ${ }^{64}$ Samsun NN plants offering replicative functions in trans for fulllength infectious RNA3 of AlMV (NF1-g24). The second one utilized Nicotiana benthamiana and spinach (Spinacia oleracea) plants using autonomously cloning tobacco mosaic virus (TMV) lacking fundamental CP (Av/A4-g24). Recombinant virus consisting of the chimeric rabies virus epitope was obtained from infected transgenic N. tabacum cV. Samsun NN plants and was utilized for parenteral immunization of mice. Mice immunized with recombinant virus were shielded against challenge infection. Depending upon the formerly demonstrated efficacy of this plant virusbased experimental rabies vaccine when administered orally into mice in virus-infected unprocessed raw spinach leaves, its efficacy in human volunteers was accessed. Three out of five volunteers who had formerly been immunized against rabies virus through a conventional vaccine specifically responded against the peptide antigen after consuming recombinant virus infected spinach leaves. When rabies virus non-immune volunteers were fed the same material, 5/9 demonstrated strong antibody responses to either rabies virus or AlMV. Three of the individuals showed detectable levels of rabies virus- neutralizing antibodies following a single dose of conventional rabies virus vaccine, whereas none of five controls produced these antibodies. This data provides a clear indication of the potency of the plant virus-based expression systems as supplementary oral booster for rabies vaccinations.

Table 1: Results of generation of antibodies in rabies

\begin{tabular}{|l|l|l|l|l|}
\hline $\begin{array}{l}\text { Antibody response and survival of C3H } \\
\text { mice immunized with AlMV containing } \\
\text { chimeric peptide from rabies virus. } \\
\text { Group of mice }\end{array}$ & Codes & $\begin{array}{l}\text { Dose of antigen } \\
\text { (g per dose) }\end{array}$ & $\begin{array}{l}\text { Rabies neutralizing } \\
\text { antibodies }\end{array}$ & $\begin{array}{l}\text { Survival afterChallenge } \\
\text { with rabies virus }\end{array}$ \\
\hline NF1-g24 & A & 250 & $4 / 5$ & $5 / 5$ \\
\hline & B & & $5 / 5$ & $5 / 5$ \\
\hline AlMV & C & 250 & $0 / 5$ & $2 / 5$ \\
\hline & D & & $0 / 5$ & $0 / 5$ \\
\hline G5-24-N31D & E & 25 & $1 / 5$ & $1 / 3$ \\
\hline & F & & $4 / 5$ & $2 / 4$ \\
\hline
\end{tabular}

\section{In the treatment of Norwalk virus}

Recent studies using new diagnostic assays developed with recombinant NV (rNV) particles or using reverse transcription-polymerase chain reaction have shown that the epidemiologic significance of NV infections has been greatly underestimated ${ }^{65-68}$.A new approach for delivering vaccine antigens is the use of inexpensive, plentiful, plant based oral vaccines 69,70 . Usage of inexpensive, plentiful, plant based oral vaccines is a novel approach for supplying vaccine antigens. Norwalk virus capsid protein (NVCP) structured into viruslike particles was utilized as a test antigen to find out whether immune responses could be produced in volunteers who consumed transgenic potatoes. Twenty-four healthy adult volunteers were given 2 or 3 doses of transgenic potato $(n=20)$ or 3 doses of wild-type potato $(n=4)$. Each dose comprised of $150 \mathrm{~g}$ of raw, peeled, diced potato that contained $215-751 \mathrm{mg}$ of NVCP. 19 of 20 volunteers (95\%) who ingested transgenic potatoes showed considerable increases in the numbers of specific IgA antibody-secreting cells. 4 of 20 volunteers (20\%) developed specific serum IgG, and $6(30 \%)$ generated specific stool IgA. Overall, 19 out of 20 volunteers developed immune responses of some kind, although the degree of serum antibody increase was modest.

Safety: No changes in the incidence rates of nausea, 
vomiting, fever, mild cramps or diarrhea were observed among volunteers who ingested transgenic or wild-type potatoes within three days after the ingestion of the first dose of potatoes. The most common symptom observed was nausea, which occurred in 4 out of 20 (20\%) of the volunteers who ingested transgenic potatoes and 1 of 4 $(25 \%)$ volunteers who ingested wild-type potatoes. Cramps occurred in 5 of $20(25 \%)$ volunteers who ingestedtransgenic potatoes and 2 of $4(50 \%)$ volunteers who ingested wild-type potatoes 71 .

Immunogenicity: 19 out of 20 (95\%) individuals who ingested 2 to 3 doses of transgenic potatoes showed significant raise in the numbers of IgA ASCs (range: 6280/106 PBMC). The recipients of wild-type potato showed a geometric mean of 2 IgA ASCs/106 PBMC following 3 doses. 13 out of 19 IgA ASC responses were obtained following the first dose of transgenic potato. 6 out of 20 (30\%) individuals showed significant raise in IgG ASCs (range: (25-115/106 PBMC)). These circulating cells which produce specific antibodies reflect immunologic priming of the immune system of gut mucosa ${ }^{71}$.

\section{In treating Influenza}

Influenza virus infections cause a severe respiratory disease, because of which 3 to 5 million cases of serious illness are recorded worldwide yearly, including 250,000 to 500,000 fatalities. Since 2004, the virus has spread rapidly and now it has caused serious poultry disease outbreaks in many Asian countriesalong with Europe and Africa. Two main influenza surface antigens namely HA and NA have been expressed ininsect, bacteria yeast, plant and mammalian cells as soluble recombinant proteins. These were used successfully to induce protective immunity in animal models $72-77$. Recombinant soluble influenza proteins have already been tested in clinical studies for different age groups 9 78-80. More than 500 people have been contaminated with H5N1 virus with $50-60 \%$ mortality rate. Fortunately, human to human transmission hasn't been on higher side and occurred on rare occasion as most of the reportedhuman cases have had close contact with infected birds. Nevertheless, this doesn't minimize the concern for human health due to their severity of human cases and adaptive nature of virus which could mutate or re-assort and might develop the ability to spread effectively among humans. They are very effective and safe inducers potentially have broader 81 protective immune responses. In fact, InfluenzaVLP vaccines that are to be used for H1N1, H5N1, and H7N9 manufactured in different platforms have entered clinical trials $82-84$. Apart from VLPs, viral vectors carrying influenza antigens are also interesting Especially the recombinant modified vaccinia virus Ankara (MVA) vector has a very good safety profile in humans and preclinical studies with MVA-based pandemic influenza vaccines are of great potential 85,86 . An adenovirus vectorbased H5N1 vaccine checked in a clinical observation in humans pretend that this type of vaccine may have a promising future for use with poorly immunogenicvaccines in a prime boost setting in which the adenovirus- based vaccination is followed by a parenteralbooster injection with inactivated vaccine 87,88 .

\section{In the treatment of HIV}

The acquired immune deficiency syndrome (AIDS) is one of the most prominent diseases worldwide that is caused by the human immunodeficiency virus (HIV). Plant-based vaccines for HIV provide a topic of great interest to the researchers which are observed by great number of reports upon expressing HIV antigen in plants ${ }^{89}$. HIV is mostly transmitted via genitourinary and rectal mucosa where it enters by crossing the epithelial cells ${ }^{90}$. Developments on the manufacture and by putative protective proteins characterization at the antigenic level have showed the viability of this approach Since mucosal immuneresponses could be efficiently induced by the administration of vaccines onto mucosal surfaces, which offers the possibility of leading to HIV immunity ${ }^{91,} 92$. Based on the current progress in this field, it is clear that a detailed immune logical characterization for a very large number of explored antigens is yet to be performed 93,94. However, since eliciting specific and broad cellular and humoral responses are necessary requirement for prevention or reduction of severity of the HIV infection, it is a mandatory need to evaluate new protein configurations for identifying highly effective immunogens. Besides, some goals like coexpression of adjuvants will be viable by the trans plastomic technologies marking a huge contribution in this field. These advances will help us a step ahead towards the next preclinical steps, which can lead us to neutralization of HIV. Ina nutshell, plant-based vaccines have open doors to an alternative, which along with traditional approaches, might be helpful in the fight against HIV 95 .

\section{In the treatment of Corona}

Corona viruses (COVs) consist assorted group of positivesense embedded RNA viruses having genomes which range between 27-32 kb ${ }^{96}$. A biopharmaceutical company from Canada named Medicago, has successfully made virus-like particles (VLPs) of the coronavirus around 20 days following the SARS-CoV-2 genetic sequence. Despite of opting for eggbased methods to produce vaccines, this technology an encoded genetic sequence of COVID 19 spike protein is inserted into Agrobacterium, a commonly found soil bacterium which then consumed by plants ${ }^{97}$. The resulting plants generate a particle identical to virus which constitute of plant lipid membrane and COVID-19 spike protein. Medicago is employing Nicotiana benthamiana, a plant that shares identical family to that of tobacco plant, to form VLPs of SARS-CoV2 virus (COVID-19: Medicago's Development Programs). These VLPs are identical in shape and size to coronavirus but are devoid of nucleic acid and are thus noninfectious. After successful completion of Phase- 1 clinical trials, Medicago is currently working on Phase-2 trials 98. Medicago his experienced in developing VLPs comprised of influenza virus haemagglutinin before, and have reported their safety and efficacy in animal models and in human clinical trials, too ${ }^{99}$. The production of a plant- made vaccine based upon VLPs is quite cost effectivewhen compared to its conventional counterpart 100. British- American Tobacco (BAT) through Kentucky Bio-processing (KBP), its biotech subsidiary present in US, is formulating an efficient vaccinefor COVID-19 and its pre-clinical trials are in progress ${ }^{101}$. Experts at KBP have cloned a piece of geneticsequence of SARS-CoV-2, which was utilized for potential antigen that was injected into the plants of Nicotiana benthamiana for production. The pre-clinical trials of vaccine have shown a positive immune response and will be into Phase- 1 human clinical trials very soon ${ }^{102}$. BAT has a production capacity ofapproximately 1-3 million doses per week of COVID-19 vaccines (they prepared $10 \mathrm{M}$ flu vaccines in a month and Ebola vaccine utilizing the same plant based approach 103,104 


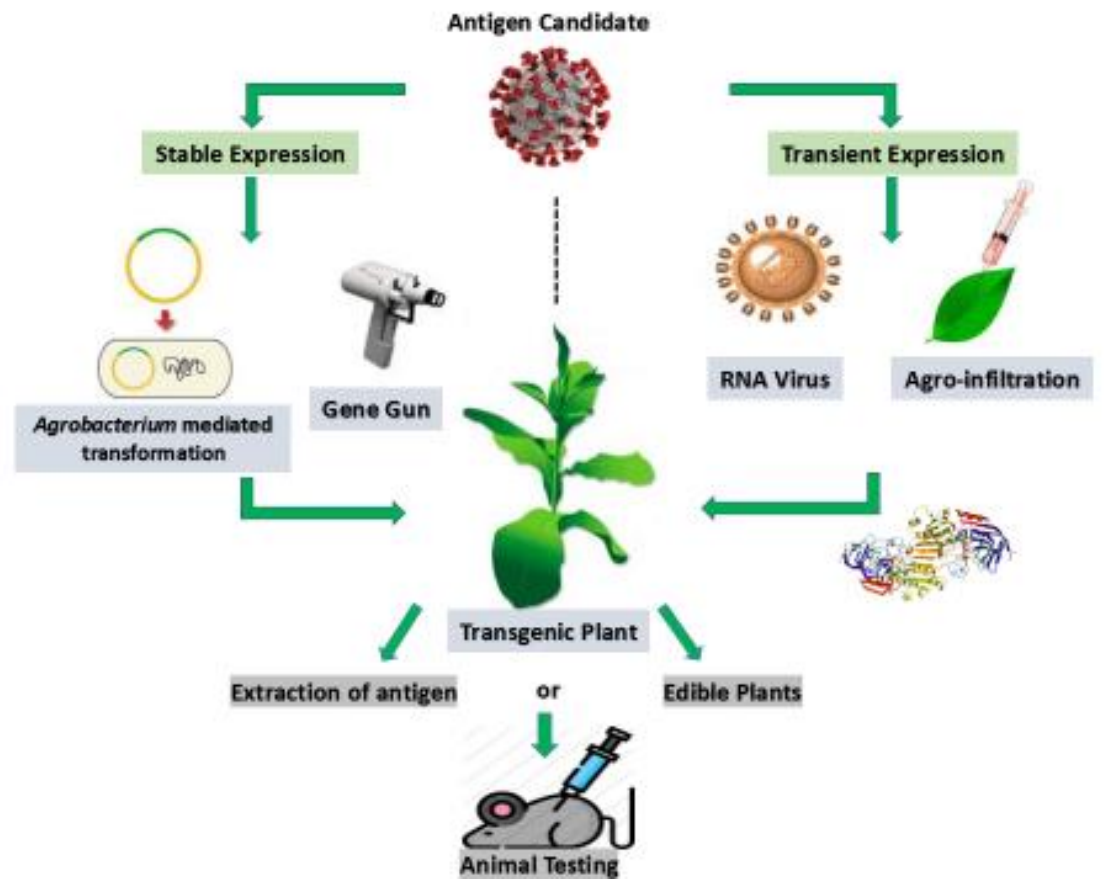

Figure 1: Schematic diagram of Plant pharming

\section{CONCLUSION}

The progress for commercialization of plant-based vaccines takes much effort and time, but it will definitely work in the future. They offer several merits in terms of safety, immunogenicity and stability in production over vaccines derived from pathogen formulation or subunit antigens and hence, has earned huge momentum as a premier vaccine platform. VLPs are deficit of viral nucleic acid and are noninfectious. Hence, are safer alternatives of vaccine than attenuated or inactivated viruses. Moreover, VLPs are more stable than subunit vaccines and can be manufactured with the help of recombinant technology in expression systems with no requirement of the capability to aid viral replication. This plant engineering technology works in the treatment of viruses like Hepatitis B, Ebola, Papilloma virus, Norwalk, Influenza, HIV and Corona. Many key points are essential for the development of a broadly effective GMP-compliant regulatory framework for clinical application of plant-based vaccines in humans. The challenge is to facilitate the procedures without compromising quality, which is a prerequisite for manufacturing plant-based human vaccines.

Acknowledgement: The authors are thankful to

Principal Dr. Rakesh K. Patel and Professor Dr. Riddhi Trivedi for all the help.

Conflict of Interest: The authors declare that there is no conflict of interest

\section{Abbriviations:}

VLS: virus-like particles, BeYDV: bean yellow dwarf virus, HBV: Hepatitis B virus, HBsAg: Hepatitis B surface antigen, ER: Endoplasmic reticulum, SHBs: small HBV surface protein, EBOV: Ebola virus, mAbs: monoclonal antibodies, ED50: median effective dose, HPV: Human papillomavirus, ELISA: enzyme-linked immunosorbent assay, PCR: polymerase chain reaction, AIMV: alfalfa mosaic virus, CP: coat protein, rNV: recombinant NV , NVCP: Norwalk virus capsid protein, PBMC: peripheral blood mononuclear cell, AIDS: acquired immune deficiency syndrome, HIV: human immunodeficiency virus, COVs: Corona viruses, KBP: Kentucky Bio-processing, BAT: British- American Tobacco.

\section{REFERENCES}

1. Chen $Q$ and Lai H. Plant-derived virus-like particles as vaccines. Human Vaccines \& Immunotherapeutics 2013; 9(1):26-49 https://doi.org/10.4161/hv.22218

2. Roldão A, Mellado MC, Castilho LR, CarrondoMJ, Alves PM. Viruslike particles invaccine development. Expert Rev Vaccines 2010; 9:1149-76. https://doi.org/10.1586/erv.10.115

3. Chackerian B. Virus-like particles: flexible platforms for vaccine development. Expert Rev Vaccines 2007; 6:381-90 https://doi.org/10.1586/14760584.6.3.381

4. Chen Q. Expression and manufacture of pharmaceutical proteins in genetically engineered horticultural plants. In: Mou B, Scorza $\mathrm{R}$, eds. Transgenic Horticultural Crops: Challenges and Opportunities - Essays by Experts. Boca Raton: Taylor \& Francis 2011:86-126. https://doi.org/10.1201/b10952-5

5. Faye L, Gomord V. Success stories in molecular farming- a brief overview. Plant Biotechnol J 2010; 8:525-8 https://doi.org/10.1111/j.1467-7652.2010.00521.x

6. Lai H, Engle M, Fuchs A, Keller T, Johnson S, Gorlatov S, et al. Monoclonal antibody producedin plants efficiently treats West Nile virus infection in mice. Proc Natl Acad Sci USA 2010; 107:2419- 24; https://doi.org/10.1073/pnas.0914503107

7. Lai H, He J, Engle M, Diamond MS, Chen Q. Robust production of virus-like particles and monoclonal antibodies with geminiviral replicon vectors in lettuce. Plant Biotechnol J 2012; 10:95- 104. https://doi.org/10.1111/j.1467-7652.2011.00649.x

8. Lai H, Chen Q. Bioprocessing of plant-derived virus like particles of Norwalk virus capsid protein under current Good Manufacture Practice regulations. Plant Cell Rep 2012; 31:573- 84 https://doi.org/10.1007/s00299-011-1196-6

9. Chen Q. Expression and Purification of Pharmaceutical Proteins in Plants Biological Engineering 2008; 1:291-321. https://doi.org/10.13031/2013.26854

10. Davies HM. Review article: commercialization of whole-plant systems for biomanufacturing of protein products: evolution and prospects. Plant Biotechnol J 2010; 8:845-61. https://doi.org/10.1111/j.1467-7652.2010.00550.x

11. Chen Q, Tacket CO, Mason H, Mor T, Cardineau GA, Arntzen C. Subunit vaccines produced using plant biotechnology. In: Levine MM, ed. New Generation Vaccines. New York: Inform a Healthcare USA, Inc. 2009:306-15. 
12. Komarova TV, Baschieri S, Donini M, Marusic C, Benvenuto E, Dorokhov YL. Transient expression systems for plant-derived biopharmaceuticals. Expert Rev Vaccines 2010; 9:859-76. https://doi.org/10.1586/erv.10.85

13. Lico C, Chen Q, Santi L. Viral vectors for production of recombinant proteins in plants. J Cell Physiol 2008; 216:366-77. https://doi.org/10.1002/jcp.21423

14. Huang Z, Chen Q, Hjelm B, Arntzen C, Mason HA. DNA replicon system for rapid high- level production of virus-like particles in plants. Biotechnol Bioeng 2009; 103:706-14. https://doi.org/10.1002/bit.22299

15. Santi L, Batchelor L, Huang Z, Hjelm B, Kilbourne J, Arntzen CJ, et al. An efficient plant viral expression system generating orally immunogenic Norwalk virus-like particles. Vaccine 2008; 26:1846-54. https://doi.org/10.1016/j.vaccine.2008.01.053

16. He J, Lai H, Brock C, Chen Q. A Novel System for Rapid and CostEffective Production of Detectionand Diagnostic Reagents of West Nile Virus in Plants. J Biomedicine and Biotechnology 2012; 1-10. https://doi.org/10.1155/2012/106783

17. Saldaña S, Esquivel Guadarrama F, Olivera Flores TdeJ, Arias N, López S, Arias C, et al. Productionof rotavirus-like particles in tomato (Lycopersicon esculentum L.) fruit by expression of capsid proteins VP2 and VP6 and immunological studies. Viral Immunol 2006; 19:42-53. https://doi.org/10.1089/vim.2006.19.42

18. Yang Y, Li X, Yang H, Qian Y, Zhang Y, Fang R, et al. Immunogenicity and virus-like particle formation of otavirus capsid proteins produced in transgenic plants. Sci China Life Sci 2011; 54:82-9. https://doi.org/10.1007/s11427-010-4104-3

19. Tacket CO, Mason HS, Losonsky G, Estes MK, Levine MM, Arntzen CJ. Human immune responsesto a novel Norwalk virus vaccine delivered in transgenic potatoes. J Infect Dis 2000; 182(1):302-5. https://doi.org/10.1086/315653

20. Tacket CO, Mason HS, Losonsky G, Clements JD, Levine MM, Arntzen CJ. Immunogenicity in humans of a recombinant bacterial antigen delivered in a transgenic potato. Nat Med 1998; 4(5):607-9. https://doi.org/10.1038/nm0598-607

21. Richter LJ, Thanavala Y, Arntzen CJ, Mason HS. Production of hepatitis B surface antigen in transgenic plants for oral immunization. Nat Biotechnol 2000; 18(3):1167-71. https://doi.org/10.1038/81153

22. Kong Q, Richter L, Yang YF, Arntzen C, Mason HS, Thanavala Y. Oral immunization with hepatitisB surface antigen expressed intransgenic plants. Proc Natl Acad Sci USA 2001; 98(20):1153944. https://doi.org/10.1073/pnas.191617598

23. Kane MA. Status of hepatitis B immunization programmes in 1998. Vaccine 1998; 16(Suppl):S104-8. https://doi.org/10.1016/S0264-410X(98)00308-9

24. Beutels P. Economic evaluations applied to HB vaccination: general observations. Vaccine 1998;16(Suppl):S84-92. https://doi.org/10.1016/S0264-410X(98)00305-3

25. Hilleman MR. Plasma-derived hepatitis B vaccine: a breakthrough in preventive medicine. In: Ellis RW, editor. Hepatitis B vaccines in clinical practice. New York: Marcel Dekker; 1993. p. 17-40.

26. Vyas GN, Rao KR, Ibrahim AB. Australia antigen (hepatitis B antigen): a conformational antigen dependent on disulfide bonds.Science 1972;178:1300-1.

https://doi.org/10.1126/science.178.4067.1300

27. Sukeno N, Shirachi R, Yamaguchi J, Ishida N. Reduction and reoxidation of Australia antigen: lossand reconstitution of particle structure and antigenicity. J Virol 1972; 9(1):182-3. https://doi.org/10.1128/JVI.9.1.182-183.1972

28. Sitrin RD, Wampler DE, Ellis RW. Survey of licensed hepatitis B vaccines and their production processes. In: Ellis RW, editor. Hepatitis B vaccines in clinical practice. New York: Marcel Dekker; 1993:83-102.
29. Mason HS, Lam DMK, Arntzen CJ. Expression of hepatitis B surface antigen in transgenic plants. Proc Natl Acad Sci 1992; 89(24):11745-9. https://doi.org/10.1073/pnas.89.24.11745

30. Eble BE, Lingappa VR, Ganem D. Hepatitis B surface antigen: an unusual secreted protein initially synthesized as a transmembrane polypeptide. Mol Cell Biol 1986; 6(5):1454-63. https://doi.org/10.1128/MCB.6.5.1454

31. Petre J, Van WF, De NB. Development of a hepatitis B vaccine from transformedyeast cells. Postgrad Med J 1987; 63(2):73-81.

32. McAleer WJ, Buynak EB, Maigetter RZ, Wampler E, Miller WJ, Hilleman MR. Human hepatitis B vaccine from recombinant yeast Nature 1984; 307(5947):178-80. https://doi.org/10.1038/307178a0

33. Mishiro S, Imai M, Takahashi K, et al. A 49,000-dalton polypeptide bearing all antigenic determinants and full immunogenicity of 22-nm hepatitis B surface antigen particles. J Immunol 1980; 124(4):1589- 93.

34. Hauser P, Thomas HC, Water J., et al. Induction of neutralizing antibodies in chimpanzees and in humans by a recombinant yeast-derived hepatitis B surface particle. In: Zuckerman AJ, editor. Viral hepatitis and liver disease. New York: Alan R. Liss; 1988:1031-7.

35. Elliot AY, Morges W, Olson MG. Experience in manufacturing, testing, and licensing a hepatitis B vaccine produced by recombinant technology. In: Lubiniecki AS, Vargo SA, editors. Regulatory practice for biopharmaceutical production. New York: Wiley-Liss; 1994:256-69.

36. Alibek K. Biohazard: The Chilling True Story of the Largest Covert Biological Weapons Program in the World-Told from Inside by the Man Who Ran It (Random House, New York) 1999

37. Wilson JA. Epitopes involved in antibody-mediated protection from Ebola virus. Science 2000; 287:1664-1666. https://doi.org/10.1126/science.287.5458.1664

38. Giritch A, et al. (2006) Rapid high-yield expression of full-size IgG antibodies in plants coinfected with noncompeting viral vectors. Proc Natl Acad Sci USA 103:14701-14706. https://doi.org/10.1073/pnas.0606631103

39. Marillonnet $S$, et al. In planta engineering of viral RNA replicons: efficient assembly by recombination of DNA modules delivered by Agrobacterium. Proc Natl Acad Sci USA 2004; 101:68526857. https://doi.org/10.1073/pnas.0400149101

40. Steplewski Z, et al. (1988) Biological activity of human-mouse IgG1, IgG2, IgG3, and IgG4chimeric monoclonal antibodies with antitumor specificity. Proc Natl Acad Sci 1988; 85:4852-4856. https://doi.org/10.1073/pnas.85.13.4852

41. Lu B, Kumar A, Castellsague X, Giuliano AR. Efficacy and safety of prophylactic vaccines against cervical HPV infection and diseases among women: a systematic review \& meta- analysis. BMC Infect Dis 2011; 11:13. https://doi.org/10.1186/14712334-11-13

42. Romanowski B. Long term protection against cervical infection with the humanpapillomavirus: review of currently available vaccines. Hum Vaccin 2011; 7(2):161-9. https://doi.org/10.4161/hv.7.2.13690

43. Einstein MH, Baron M, Levin MJ, Chatterjee A, Edwards RP, Zepp $F$, et al. Comparison of the immunogenicity and safety of Cervarix and Gardasil human papillomavirus (HPV) cervical cancer vaccines in healthy women aged 18-45 years. Hum Vaccin 2009; 5(10):705-19. https://doi.org/10.4161/hv.5.10.9518

44. Draper E, Bissett SL, Howell-Jones R, Waight P, Soldan K, Jit M. A randomized, observer- blinded immunogenicity trial of Cervarix((R)) and Gardasil((R)) human papillomavirusvaccines in 12-15 year old girls. PLoS One 2013; 8(5):e61825. https://doi.org/10.1371/journal.pone.0061825

45. Kemp TJ, Garcia-Pineres A, Falk RT, Poncelet S, Dessy F, Giannini SL, et al. Evaluation of systemic and mucosal anti-HPV16 and anti-HPV18 antibody responses from vaccinated women. Vaccine 2008; 26(29-30):3608-16. 
https://doi.org/10.1016/j.vaccine.2008.04.074

46. Suzich JA, Ghim SJ, Palmer-Hill FJ, White WI, Tamura JK, Bell JA, et al. Systemic immunization with papillomavirus L1 protein completely prevents the development of viral mucosal papillomas. PNAS 1995; 92(25):11553-7.

https://doi.org/10.1073/pnas.92.25.11553

47. Breitburd F, Kirnbauer R, Hubbert NL, Nonnenmacher B, TrinDinh-Desmarquet C, OrthG, et al. Immunization with viruslike particles from cottontail rabbit papillomavirus (CRPV) can protect against experimental CRPV infection. J Virol 1995; 69(6):3959-63. https://doi.org/10.1128/jvi.69.6.39593963.1995

48. Longet S, Schiller JT, Bobst M, Jichlinski P, Nardelli-Haefliger D. A murine genital-challenge modelis a sensitive measure of protective antibodies against human papillomavirus infection. J Virol 2012; 85(24):13253-9.

https://doi.org/10.1128/JVI.06093-11

49. Schiller JT, Lowy DR. Immunogenicity testing in human papillomavirus viruslike- particle vaccine trials. J Infect Dis 2009; 200(2):166-71. https://doi.org/10.1086/599988

50. Stanley M. Potential mechanisms for HPV vaccine-induced longterm protection. Gynecol Oncol 2010; 118(1):S2-7. https://doi.org/10.1016/j.ygyno.2010.04.002

51. Draper E, Bissett SL, Howell-Jones R, Edwards D, Munslow G, Soldan K, et al. Neutralization of non- vaccine human papillomavirus pseudoviruses from the A7 and A9 species groups by bivalent HPV vaccine sera. Vaccine 2011; 29(47):8585-90. https://doi.org/10.1016/j.vaccine.2011.09.021

52. Giannini SL, Hanon E, Moris P, Van Mechelen M, Morel S, Dessy F, et al. Enhanced humoral and memory B cellular immunity using HPV16/18 L1 VLP vaccine formulated with the MPL/aluminium salt combination (AS04) compared to aluminium salt only. Vaccine 2006; 24(33-34):5937-49.

https://doi.org/10.1016/j.vaccine.2006.06.005

53. Pastrana DV, Buck CB, Pang YY, Thompson CD, Castle PE, FitzGerald PC, et al. Reactivity of human sera in a sensitive, highthroughput pseudovirus based papillomavirus neutralization assay for HPV16 and HPV18. Virology 2004; 321(2):205-16. https://doi.org/10.1016/j.virol.2003.12.027

54. Hamamoto H, Sugiyama Y, Nakagawa N, Hashida E, Matsunaga Y, Takemoto $S$, et al. A new tobacco mosaic virus vector and its use for the systemic production of angiotensin-I- converting enzyme inhibitor in transgenic tobacco and tomato. Biotechnology 1993; 11:930 2. https://doi.org/10.1038/nbt0893-930

55. Usha R, Rohll JB, Spall VE, Shanks M, Maule AJ, Johnson JE, et al. Expression of an animal virus antigenic site on the surface of a plant virus particle. Virology 1993; 197:366- 74. https://doi.org/10.1006/viro.1993.1598

56. Porta C, Spall VE, Loveland J, Johnson JE, Barker PJ, Lomonossoff G. Development of cowpea mosaic virus as a high-yielding system for the presentation of foreign peptides. Virology 1994; 202:949-55. https://doi.org/10.1006/viro.1994.1417

57. Fitchen J, Beachy RN, Hein MB. Plant virus expressing hybrid coat protein with added murine epitope elicits autoantibody response. Vaccine 1995; 13:1051-7. https://doi.org/10.1016/0264-410X(95)00075-C

58. McLain L, Porta C, Lomonossoff G, Durrani Z, Dimmock NJ. Human immunodeficiency virus type1- neutralizing antibodies raised to a glycoprotein 41 peptide expressed on the surface of a plant virus. AIDS Res Hum Retroviruses 1995; 11:327-34. https://doi.org/10.1089/aid.1995.11.327

59. Turpen TH, Reini SJ, Charoenvit Y, Hoffman SL, Fallarme V, Grill LK. Malarial epitopes expressedon the surface of recombinant tobacco mosaic virus. Biotechnology 1995; 13:53- 7. https://doi.org/10.1038/nbt0195-53

60. Yusibov V, Modelska A, Steplewski K, Agadjanyan M, Weiner D, Hooper C, et al. Antigens produced in plants by infection with chimeric plant viruses immunize against rabies virus and HIV-1. Proc Natl Acad Sci USA 1997; 94:5784-8.
61. Modelska A, Dietzschold B, Fleysh N, Fu ZF, Steplewski K, Hooper $\mathrm{C}$, et al. Immunization against rabies with plant-derived antigen. Proc Natl Acad Sci USA 1998; 95:2481-5. https://doi.org/10.1073/pnas.95.5.2481

62. Dalsgaard K, Uttenthal A, Jones TD, Xu F, Merryweather A, Hamilton WDO, et al. Plant- derived vaccine protects target animals gainst viral disease. Nat Biotechnol 1997; 15:248-52. https://doi.org/10.1038/nbt0397-248

63. Belanger H, Fleysh N, Cox S, Bartman B, Deepali D, Trudel M, et al. Human respiratory syncytial virus vaccine antigen produced in plants. FASEB J 2000; 78:1213-7. https://doi.org/10.1096/fj.000144com

64. Yusibov V, Hooper DC, Spitsin SV, Fleysh N, Kean RB, Mikheeva T, Deka D et. al. Expression in plants and immunogenicity of plant virus-based experimental rabies vaccine. Vaccine 2002; 20: 3155-3164. https://doi.org/10.1016/S0264$410 \mathrm{X}(02) 00260-8$

65. Pang XL, Joensuu J, Vesikari T. Human calicivirus-associated sporadic gastroenteritis in Finnish children less than two years of age followed prospectively during a rotavirus vaccine trial. Pediatr Infect Dis J 1999; 18:420-6. https://doi.org/10.1097/00006454-199905000-00005

66. Fankhauser RL, Noel JS, Monroe SS, Ando T, Glass RI. Molecular epidemiology of "Norwalk-like viruses" in outbreaks of gastroenteritis in the United States. J Infect Dis 1998; 178:15718. https://doi.org/10.1086/314525

67. Vinje' J, Altena SA, Koopmans MPG. The incidence and genetic variability of small round structured viruses in outbreaks of gastroenteritis in The Netherlands. J Infect Dis 1997; 176:13748. https://doi.org/10.1086/517325

68. Sharp TW, Hyams KC, Watts D, et al. The epidemiology of Norwalk virus during an outbreak of acute gastroenteritis aboard a US aircraft carrier. J Med Virol 1995; 45:61-7. https://doi.org/10.1002/jmv.1890450112

69. Kusnadi AR, Hood EE, Witcher DR, Howard JA, Nikolov ZL. Production and purification of two recombinant proteins from transgenic corn. Biotechnol Prog 1998; 14:149-55. https://doi.org/10.1021/bp970138u

70. Arakawa T, Chong DKX, Langridge WHR. Efficacy of a food plantbased oral cholera toxin B subunit vaccine. Nat Biotechnol 1998; 16:292-7. https://doi.org/10.1038/nbt0398-292

71. Tacket CO, Mason HS, Losonsky G, Estes MK, Levine MM, Arntzen CJ. Human immune responses to a novel norwalk virus vaccine delivered in transgenic potatoes. J Infect Disease. 2000 Jul; 182(1):302-5. https://doi.org/10.1086/315653

72. D'Aoust MA, Lavoie PO, Couture MM, Trepanier S, Guay JM, Dargis M, Mongrand S, Landry N., Ward BJ, Vezina LP. Influenza virus-like particles produced by transient expression in nicotiana benthamiana induce a protective immune response against a lethal viral challenge in mice. Plant Biotechnol. J. 2008 6:930-940. https://doi.org/10.1111/j.1467-7652.2008.00384.x

73. Verma S, Dimitrova M, Munjal A, Fontana J, Crevar CJ, Carter DM Ross TM, Khurana S., Golding H. Oligomeric recombinant h5 ha1 vaccine produced in bacteria protects ferrets from homologous and heterologous wild-type h5n1 influenza challenge and controls viral loads better than subunit h5n 1 vaccine by eliciting high-affinity antibodies. J. Virol. 2012; 86:12283-12293. https://doi.org/10.1128/JVI.01596-12

74. Bosch BJ, Bodewes R, de Vries RP, Kreijtz JH, Bartelink W, van Amerongen G, RimmelzwaanGF, de Haan CA, Osterhaus AD, Rottier PJ. Recombinant soluble, multimeric ha and na exhibit distinctive types of protection against pandemic swine-origin 2009 a(h1n1) influenza virus infectionin ferrets. J. Virol. 2010; 84:10366-10374. https://doi.org/10.1128/JVI.01035-10

75. Johansson BE. Immunization with influenza a virus hemagglutinin and neuraminidase produced in recombinant baculovirus results in a balanced and broadened immune response superior to conventional vaccine. Vaccine. 1999; 17:2073-2080. https://doi.org/10.1016/S0264- 


\section{X(98)00413-7}

76. Martinet W, Saelens X, Deroo T, Neirynck S, Contreras R, Min Jou $\mathrm{W}$, Fiers W. Protection of mice against a lethal influenza challenge by immunization with yeast-derived recombinant influenza neuraminidase. Eur. J. Biochem./FEBS. 1997; 247:332338. https://doi.org/10.1111/j.1432-1033.1997.00332.x

77. Deroo T, Jou WM., Fiers W. Recombinant neuraminidase vaccine protects against lethal influenza. Vaccine. 1996; 14:561-569. doi: https://doi.org/10.1016/0264-410X(95)00157-V

78. Treanor JJ, Schiff GM, Couch RB, Cate TR, Brady RC, Hay CM, Wolff M, She D, Cox MM. Dose-related safety and immunogenicity of a trivalent baculovirus-expressed influenza-virus hemagglutinin vaccine in elderly adults. J. Infect. Dis. 2006; 193:1223-1228. https://doi.org/10.1086/503050

79. Baxter R, Patriarca PA, Ensor K, Izikson R, Goldenthal KL, Cox MM. Evaluation of the safety, reactogenicity and immunogenicity of flublok(r) trivalent recombinant baculovirus-expressed hemagglutinin influenza vaccine administered intramuscularly to healthy adults 50-64 years of age. Vaccine. 2011; 29:22722278. https://doi.org/10.1016/j.vaccine.2011.01.039

80. Chichester JA, Jones RM, Green BJ, Stow M, Miao F, Moonsammy G, Streatfield SJ, Yusibov V. Safety and immunogenicity of a plant-produced recombinant hemagglutinin-based influenza vaccine (hai-05) derived from a/indonesia/05/2005 (h5n1) influenza virus: A phase 1 randomized, double-blind, placebocontrolled, dose-escalation study in healthy adults. Viruses. 2012; 4:3227- 3244. https://doi.org/10.3390/v4113227

81. Bright RA, Carter DM, Daniluk S, Toapanta FR, Ahmad A, Gavrilov V, Massare M, Pushko P, Mytle N, Rowe T, et al. Influenza viruslike particles elicit broader immune responses than whole virion inactivated influenza virus or recombinant hemagglutinin. Vaccine. 2007; 25:3871- 3878. https://doi.org/10.1016/j.vaccine.2007.01.106

82. Fries LF, Smith GE, Glenn GM. A recombinant virus like particle influenza a (h7n9) vaccine. N.Engl. J. Med. 2013; 369:2564-2566. https://doi.org/10.1056/NEJMc1313186

83. Landry N, Ward BJ, Trepanier S, Montomoli E, Dargis M, Lapini G, Vezina LP. Preclinical and clinical development of plant-made virus-like particle vaccine against avian h5n1 influenza. PLoS One. 2010; 5. https://doi.org/10.1371/journal.pone.0015559

84. Clinicaltrials.Gov. [(accessed on 10 July 2014)]; Available online: http://www.clinicaltrials.gov.

85. Kreijtz JH, Suzer Y, Bodewes R, Schwantes A, van Amerongen G, Verburgh RJ, de Mutsert G van den Brand J, van Trierum SE, Kuiken T, et al. Evaluation of a modified vaccinia virus ankara (mva)- based candidate pandemic influenza a/h1n1 vaccine in the ferret model. J. Gen. Virol. 2010; 91:2745- 2752. https://doi.org/10.1099/vir.0.024885-0

86. Rimmelzwaan GF, Sutter G. Candidate influenza vaccines based on recombinant modified vaccinia virus ankara. Expert Rev. Vaccines. 2009; 8:447-454. https://doi.org/10.1586/erv.09.4

87. Gurwith M, Lock M, Taylor EM, Ishioka G, Alexander J, Mayall T, Ervin JE, Greenberg RN,Strout C, Treanor JJ, et al. Safety and immunogenicity of an oral, replicating adenovirus serotype 4 vector vaccine for $\mathrm{h} 5 \mathrm{n} 1$ influenza: A randomised, double-blind, placebo-controlled, phase 1 study. Lancet Infect. Dis. 2013; 13:238-250. https://doi.org/10.1016/S1473-3099(12)70345-6

88. Eric O. Freed. Influenza Vaccines: A Moving Interdisciplinary Field. Viruses. 2014 Oct; 6(10):3809- 3826 https://doi.org/10.3390/v6103809

89. Karlsson GB, Fouchier RA, Phogat S, Burton DR, Sodroski J, Wyatt RT The challenges of eliciting neutralizing antibodies to HIV-1 and to influenza virus. Nat Rev Microbiol 2008; 6:143-155. https://doi.org/10.1038/nrmicro1819

90. Hladik F, Hope TJ. HIV infection of the genital mucosa in women. Curr HIV/AIDS Rep 2009; 6:20-28. https://doi.org/10.1007/s11904-009-0004-1
91. Lamm ME. Interactions of antigens and antibodies at mucosal surfaces. Annu Rev Microbiol 1997; 51:311-340. https://doi.org/10.1146/annurev.micro.51.1.311

92. Levine MM. Immunization against bacterial diseases of the intestine. J Pediatr Gastroenterol Nutr 2000; 31:336-355. https://doi.org/10.1097/00005176-200010000-00003

93. Hone DM,Wu S, Powell RJ, Pascual DW, Van Cott J, McGhee J, Fouts TR, Tuskan RG, Lewis GK. Optimization of live oral Salmonella-HIV-1 vaccine vectors for the induction of HIVspecificmucosal and systemic immune responses. J Biotechnol 1996; 44:203-207. https://doi.org/10.1016/01681656(95)00151-4

94. Stevens R, Howard KE, Nordone S, Burkhard M, Dean GA (2004) Oral immunization with recombinant listeria monocytogenes controls virus load after vaginal challenge with feline immunodeficiency virus. J Virol 2004; 78:8210-8218. https://doi.org/10.1128/JVI.78.15.8210-8218.2004

95. Mendoza SR, Infante NR, Alonso DG and Fierros LM. Current status and perspectives of plant- based candidate vaccines against the human immunodeficiency virus (HIV). Plant Cell Reports 2012; 31:495-511. https://doi.org/10.1007/s00299011-1194-8

96. Dent SD, Xia D, Wastling JM, Neuman BW, Britton P, Maier HJ. The proteome of the infectious bronchitis virus Beau-R virion. J. Gen. Virol. 2015; 96:3499-3506. https://doi.org/10.1099/jgv.0.000304

97. Krenek P, Šamajová O, Luptovciak I, Doskocilova A, Komis G, Šamaj J. Transient plant transformation mediated by Agrobacterium tumefaciens: Principles, methods and applications. Biotechnol. Adv. 2015; 33:1024-1042. https://doi.org/10.1016/j.biotechadv.2015.03.012

98. Rosales-Mendoza S, Márquez-Escobar VA, González-Ortega $\mathrm{O}$, Nieto-Gómez, R, Arévalo- Villalobos JI. What Does Plant- Based Vaccine Technology Offer to the Fight against COVID-19? Vaccines 2020; 8:183. https://doi.org/10.3390/vaccines8020183

99. Pillet S, Couillard J, Trépanier S, Poulin JF, Yassine-Diab B, Guy B, Ward BJ, Landry N. Immunogenicity and safety of a quadrivalent plant-derived virus like particle influenza vaccine candidateTwo randomized Phase II clinical trials in 18 to 49 and 50 years old adults. PLoS ONE 2019; 14. https://doi.org/10.1371/journal.pone.0216533

100. Rybicki E. History and Promise of Plant-Made Vaccines for Animals. In Prospects of Plant-Based Vaccines in Veterinary Medicine; Springer Science and Business Media LLC: Berlin/Heidelberg, Germany, 2018; 1-22. https://doi.org/10.1007/978-3-319-90137-4_1

101. Gretler C. Tobacco-Based Coronavirus Vaccine Poised for Human Tests Bloomberg, May 15. Available online: https://www.bloomberg.com/news/articles/2020-0515/cigarette-maker-s- coronavirus-vaccine-poised-for-humantests (accessed on 24 December 2020).

102. Palca J. Tobacco Plants Contribute Key Ingredient For COVID-19 Vaccine. 2020. Available online:https://www.npr.org/sections/healthshots/2020/10/15/923210562/tobacco-plants- contribute-keyingredient-for-covid-19vaccine\#: \{\} :text=Historically $\% 2 \mathrm{C} \% 20$ tobacco $\% 20$ plants $\% 20$ are $\%$ 20responsible,be $\% 20$ used $\% 20$ in $\% 20$ a $\% 20$ vaccine (accessed on 20 December 2020).

103. Mullan K. Tobacco Giant BAT Says it Could be Making 1 to 3 Million COVID-19 Vaccines a Weekby June. 2020. Available online: https://www.derryjournal.com/news/people/tobaccogiant-bat- says-it- could-be-making-1-3-million-covid-19vaccines-week-june-2526933 (accessed on 24 December 2020).

104. Mahmood N, Nasir SB and Hefferon K. Plant-Based Drugs and Vaccines for COVID-19. Vaccines. 2021; 9:15. https://doi.org/10.3390/vaccines9010015 